\title{
Critical Success Factors for SMEs: An Empirical Study in the UK Chemical Distribution Industry
}

\author{
Evripidis Lampadarios ${ }^{1}$ \\ ${ }^{1}$ School of Strategy, Leeds Business School, Leeds Beckett University, Leeds, W. Yorkshire, UK \\ Correspondence: Evripidis Lampadarios, School of Strategy, Leeds Business School, Leeds Beckett University, \\ The Rose Bowl, Leeds, W. Yorkshire, LS1 3HE, UK. Tel: 440-777-614-6471. E-mail: \\ e.lampadarios@leedsbeckett.ac.uk
}

Received: May 26, 2016

doi:10.5539/ijbm.v11n7p67
Accepted: May 18, 2016

Online Published: June 18, 2016

\begin{abstract}
The UK chemical distribution industry, which is a well-established, fragmented, subject to strong consolidation, significant part of the chemical industry and a major contributor to the UK economy and employment, remains largely unexplored, with no research in the factors contributing to SMEs success. This is the first study to identify the factors critical to small business success and provide an integrative perspective in the specific industry. The research is based on the opinions of owners and very senior managers (Managing Directors, Directors, CEOs and CFOs), an approach extensively used by other researchers. A total of 180 SMEs fulfilling the criteria of this study are identified with 118 owners/managers participating, generating a very satisfactory response rate of $65.5 \%$. Regulatory Compliance, Entrepreneurial Orientation, Customer Relations Management, Market and Product development, Prior Work Experience and Management Skills, Human Capital, Economic Environment and Strategic Planning are established as critical success factors (CSFs). Findings suggest that success is a multidimensional phenomenon where both firm-internal and firm-external factors need to be optimal simultaneously; satisfying one or two factors does not necessarily guarantee success. Strong interrelationships are also revealed amongst the critical and non-critical success factors. The paper contributes towards the integration of SMEs success factors theories and provides guidelines to various stakeholders and policy-makers to improve strategy formulation and decision-making process in supporting chemical distribution SMEs.
\end{abstract}

Keywords: critical success factors, SMEs, UK chemical distribution industry

\section{Introduction}

Small and medium-sized enterprises (SMEs) are the focus of political, business and management research (Amoros, Bosma, \& Levie, 2013; Dobbs \& Hamilton, 2007; Lussier \& Halabi, 2014) with their benefits firmly embedded in the business literature. They are integral to contemporary economic and social regeneration (Franco \& Haase, 2010; Unger, Rauch, Frese, \& Rosenbusch, 2011), essential for the establishment of a solid industrial base (Smallbone, Welter, Voytovich, \& Egorov, 2010), key driver for innovation and R\&D (European Union, 2015) and above all significant contributors to employment generation (Lussier \& Halabi, 2010; McLarty, Pichanic, \& Sarapova, 2012; Simpson, Padmore, \& Newman, 2012). Despite their well-established importance, there is still no universally accepted definition for SMEs with significant variations in different countries (Smallbone et al., 2010; Unger et al., 2011), no single agreed-upon definition of success (Beaver, 2002; Rogoff, Lee, \& Suh, 2004), no universally accepted model to incorporate all aspects of small business success (Chawla, Khanna, \& Chen, 2010; Lampadarios, Kyriakidou, \& Smith, in press) and with knowledge being more fragmented than cumulative (Dobbs \& Hamilton, 2007). Most importantly, SMEs tend to exhibit high failure rates and poor performance levels (Arasti, Zandi, \& Talebi, 2012; Franco \& Haase, 2010; Gray, Saunders, \& Goregaokar, 2012; Ropega, 2011) with their success and/or survival receiving an ever-increasing attention from academia and practitioners alike. Business literature features a wide range of success factors through a number of conceptual frameworks that attempt to capture aspects of SMEs success. However, their importance appears to be relative and varies with the business environment, that is the industry and country SMEs operate in; meaning that while one success factor may be of great importance in one industry or country, it may not necessarily be of equal importance in another (Benzing, Chu, \& Kara, 2009; Kader, Mohamad, \& Ibrahim, 2009; Krasniqi, Shiroka-Pula, \& Kutllovc, 2008; Lin, 2006; Simpson et al., 2012). This inevitably creates a need for more 
empirical studies to investigate the critical success factors in each individual industry and in a specific country setting.

An industry where small businesses have a particularly strong presence is the European and especially the UK chemical distribution (BCG, 2013; Chemagility, 2012; Districonsult, 2013; European Association of Chemical Distributors [FECC], 2013). However, very little is known about SMEs in the specific industry, their modus operandi and any factors contributing to their success and/or failure (Chemical Business Association [CBA], 2015; FECC, 2015). In fact, due to the wide variety of functions performed by these companies and confusion with other types of trading in the industry, there is still no universally agreed definition of a chemical distributor (Chemagility, 2012). More importantly, there has been no academic study on the success of small and medium-sized chemical distributors in the UK and even on a European level, very little research exists (Hornke, 2012); mainly attempts being made by industry consultants such as Districonsult and the Boston Consulting Group (BCG). Also, there appears to be no official statistical and/or financial data available on the companies operating in the industry (Chemagility, 2015).

The 'research problem', which also becomes the basis for this study, is the fact that critical success factors (CSFs) for SMEs depend upon and vary with the industry and country they operate in. Therefore, in order to uncover the factors critical to small business success, it is necessary to investigate these factors within a specific industry and geographical context. With the UK chemical distribution being an important yet understudied industry with very little known about small businesses and their success, a clear research gap is established. Consequently, this paper aims to identify the factors critical to the success of SMEs operating in the UK chemical distribution industry. This is the first study ever conducted in the UK for the specific industry.

\section{UK Chemical Distribution Industry}

Chemical distributors are a fragmented network, positioned between chemical producers and their customers, adding value through an extensive range of services to both customers and suppliers such as managing complexity, accessing markets, providing financing and support etc. (Chemagility, 2008; FECC, 2011). Even though chemical distribution is a well-established practice in the UK, it is severely understudied both on an academic and business level with the majority of information originating from the study of the European chemical distribution industry (Districonsult, 2013; Jung, Wolleswinkel, Hoffmann, \& Rothman, 2014; Hornke, 2013; Mortelmans \& Reniers, 2012). Similarly, there are limited statistical data available on the industry and information such as turnover, sales and margin growth, performance and future trends are drawn from industry reports (for instance Chemagility).

The UK chemical distribution industry is a growing, well-established, significant part of the chemical industry (Chemagility, 2008) and remains a significant contributor to the economy and employment (European Chemical Industry Council [CEFIC], 2012; FECC, 2013; Hornke, 2013). According to the latest data available from Chemagility (2015), in 2014 the UK chemical distribution market was worth GBP 4.42bn (EUR 5.44bn), employing circa 6,800 employees and representing 10\% of the total European chemical distribution market worth EUR 52bn. With the total number of chemical distributors in the UK being 280 and with over $75 \%$ of them being small or micro-sized enterprises (210 companies if subsidiaries of larger international groups are excluded), it is evident that SMEs have a very strong presence in the specific industry. Despite major challenges due to increasing compliance costs, reduced margins, global competition and uncertainty, the UK distribution market achieved a 6\% annual growth rate between 2005 and 2010, a 5\% growth between 2011 (GBP $4.1 \mathrm{bn}$ ) and 2014 (GBP 4.5bn) and is anticipated to grow further to GBP 5.6bn by 2020 at a rate of 3.6\%, which is higher than expected the GDP growth (Chemagility, 2015).

However, the industry, like the rest of Europe has also experienced significant industry consolidation resulting in the overall reduction of the number of companies present and increasing even more the pressure on the survival of SMEs (Chemagility, 2012; Key Note, 2011; Kronimuns, Roos, \& Stelter, 2009; Plimsoll, 2013). It is worth noting that in 2014 large enterprises and multinationals held $67 \%$ of the total UK chemical distribution market value, leaving a smaller share of 23\% (GBP 1.47bn) to all other small businesses (Chemagility, 2015).

\section{SMEs Success Factors Framework}

Given the fact that is no generally agreed framework for carrying out research in the area of SMEs success (Chawla et al., 2010; Dobbs \& Hamilton, 2007; Halabi \& Lussier, 2014; Simpson et al., 2012; Watson, Hogarth-Scott, \& Wilson, 1998), this study utilises a conceptual framework developed by Lampadarios (2015) and Lampadarios et al. (n.d.), shown in diagrammatic form in Figure 1. This is the most recently informed, highly consolidated framework based on the extant literature, including entrepreneurship and not only SMEs specific studies while incorporating factors contributory to all aspects of small business success (growth and 
non-growth) and failure. The basis of this framework is a number of influential studies and established models in the areas of SMEs and entrepreneurship which then expands to include the plethora of studies that had been conducted in varied industries and geographies from the mid-1990s until 2014 (Lampadarios et al., n.d.). In detail, the works of Dobbs and Hamilton (2007, based on a summary of 34 studies between mid-1990's and 2006), Lussier's et al. work on success and failure prediction factors (1995, 2001 and 2008; based on 25 prior studies), Chawla's et al. (1997a, 2010) studies in the USA, Mexico and China, Ropega's (2011) and Rogoff's et al. (2004) studies on small business failure, Simpson's et al. $(2004,2012)$ model of success and performance in SMEs and the Global Entrepreneurial Monitor (GEM) and Vienna Entrepreneurial studies (VES) initiatives on entrepreneurial success and failure are the basis of this framework.

Due to the size and breadth of the literature in this area, this framework focuses only on the factors that are supported by a satisfactory number of authors and disregards ones mentioned very few times in the business literature. In addition, many factors relating to the same area are deliberately grouped together for means of simplicity and efficiency; for instance 'market development' (MD) and 'product development' (PD) into 'market and product development' (MPD). Also, certain success factors such as personality, entrepreneurial orientation (EO) and prior work and management skills have multiple dimensions and as such a high degree of consolidation has been exercised.

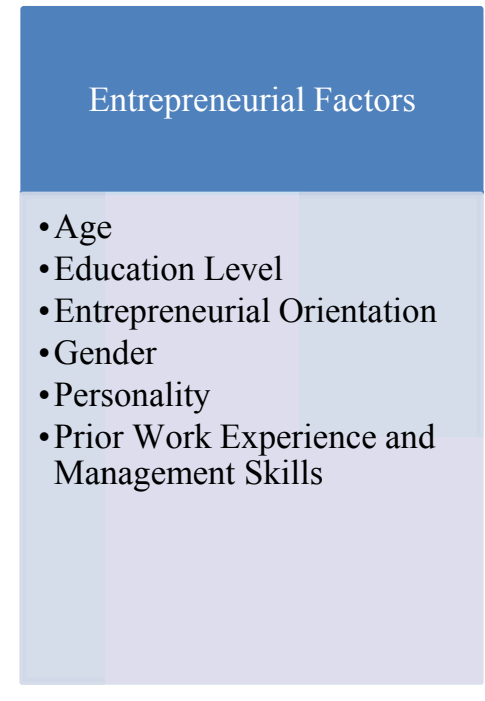

(Adopted by Lampadarios et al., n.d.).
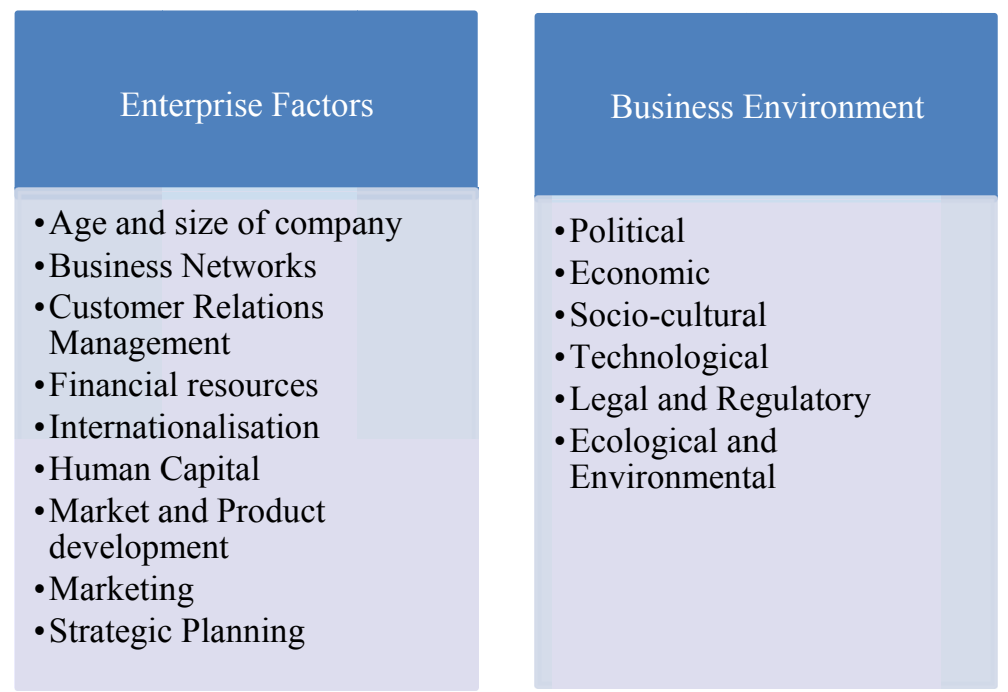

Figure 1. Conceptual framework

This framework categorises the variables of small business success into three broad categories: factors relating to the individual (personal or entrepreneurial), factors relating to the firm (enterprise) and factors relating to the external business environment. This is an approach widely used in studies investigating small business growth and success factors (for instance Andersson \& Tell, 2009; Kader et al., 2009; Krasniqi et al., 2008; Simpson et al., 2012; Smallbone \& Wyer, 2000).

The entrepreneurial (personal) factors include those variables which are considered specifically related to the owners/managers of SMEs and consist of their personality traits, characteristics and features, acquired skills, experience and background dimensions. For instance, the age and gender of owner/manager, education, motivation, personality traits and characteristics and any prior work experience and management skills. The enterprise factors are any factors relating to the business itself; that is the structural characteristics, policies and strategies of the firm. These are the age and size of company, business networks, customer relations management capabilities, financial and human resources, internationalisation, market and product development, marketing and strategic planning. The business environment factors include any external determinants reflecting the political, legal, economic, sociocultural, technological and ecological elements. This is in line with the PESTLE analysis framework comprising of political, economic, socio-cultural, technological, legal and regulatory, ecological and environmental factors. 
Also, for the purpose of this study and in line with contemporary literature (e.g. Brannback, Kiviluoto, Carsrud, \& Ostermark, 2010; Davidsson, Steffens, \& Fitzsimmons, 2009; Kiviluoto, Brannback, \& Carsrud, 2011; Steffens, Davidsson, \& Fitzsimmons, 2009), traditional financial criteria - sales growth (increase in sales turnover) and/or increase in profitability (profits and/or margin) - are used to define SMEs success. This study does not take into account the state of stability (where small firms are surviving but not growing in financial terms) and other non-financial aspects. Furthermore, as the SMEs under investigation operate in the chemical distribution industry where turnover and margin are considered key performance indicators (Chemagility, 2008; Districonsult, 2013), the above mentioned KPIs are considered the most relevant and suitable for this study.

\section{Methodology}

The aim of the study is to identify the critical success factors (CSFs) for SMEs in the UK chemical distribution industry. Based on the above theoretical framework and the categorisation of success factors in entrepreneurial, enterprise and business environment, the following hypotheses are developed:

H1: The success and sustainable growth of SMEs operating in the UK chemical distribution industry is positively influenced by six (6) entrepreneurial factors, namely: (a) Age, (b) Education level, (c) Entrepreneurial Orientation, (d) Gender, (e) Personality and (f) Prior Work Experience and Management skills of the owner/manager.

$\mathrm{H} 2$ : The success and sustainable growth of SMEs operating in the UK chemical distribution industry is positively influenced by ten (10) enterprise factors, namely: (a) Age of the company, (b) Business Networks, (c) Customer Relations Management, (d) Financial Resources, (e) Internationalisation, (f) Human Capital, (g) Market and Product development (h) Marketing, (i) Size of company and (j) Strategic Planning.

H3: The success and sustainable growth of SMEs operating in the UK chemical distribution industry is positively influenced by six (6) external (business environment) factors, namely: (a) Political, (b) Economic, (c) Socio-cultural, (d) Technological, (e) Legal and Regulatory and (f) Ecological and Environmental.

This research followed a positivistic philosophy, adopted a deductive approach and utilised a survey strategy, involving the use of self-administered questionnaires, to collect quantitative data. All participating companies were SMEs as defined by the European Union, that is enterprises employing fewer than 250 people and with an annual turnover not exceeding EUR 50 million; located in the UK; not part of a another organization or belonging to a larger corporation and without any manufacturing activity and capability.

Due to the fact that there was no official statistical data on the total number of SMEs operating in the UK chemical distribution industry, a combination of industry reports (i.e. Plimsoll, Chemagility, Keynote), business associations (i.e. the British Association of Chemical Specialties, the Chemical Business Association, the European Association of Chemical Distributors, the National Association of Chemical Distributors, the North East Process Industry cluster), internet sources (i.e. the Chemagility Online Database of Chemical Distributors and ICIS magazine), were utilised to produce a comprehensive list and thus determine the target population. Each of the identified SMEs was individually checked at a later stage to ensure that they fulfilled the criteria of the study.

The total number of SMEs in the UK chemical distribution industry satisfying the criteria was 180 . No sampling technique was used but instead a census was conducted. Owners and very senior managers (CEOs, Managing Directors and Directors) of SMEs in the UK chemical distribution industry were the key informants, an approach extensively used by other researchers (i.e. Keskin, 2006; O' Cass \& Weerawardena, 2009; Ojala, 2009; Revell, 2007; Wilson, Williams, \& Kemp, 2012). A total of 118 SMEs responded positively by returning the questionnaire, in a usable and valid form for statistical analysis, generating an overall response rate of $65.5 \%$. Thus, it can be argued that the findings of this study offer an accurate representation of SMEs operating in the UK chemical distribution industry.

\section{Results}

In order to identify the critical success factors (CSFs) for SMEs in the UK chemical distribution industry, owners/managers were asked to rank each of the suggested success factors, based on their importance to the industry. The scale was from 'Very unimportant' (1) to 'Very important' (5) with 'Unimportant' being 2, 'Neutral' being 3 and 'Important' being 4 . As the items were classified according to whether they had more or less of a characteristic, the scale used was defined as ordinal. As the collected data had a ranking and no clear numerical interpretation, non-parametric methods were utilised for their analysis. To further justify the use of non-parametric testing for the ordinal data collected, the normality of the distribution of the responses was assessed using the Kolmogorov-Smirnov test. A non-significant result - a Sig. Value more than 0.05 - indicates normality. In this study, a Sig. Value of .000 suggested violation of the assumption of normality, the distribution 
of scores was not normal and as such the use of non- parametric testing was fully justifiable (see Table 1). Participants were also asked to identify the most important entrepreneurial, enterprise and business environment factor, introducing a further element of factorisation to support the selection of the most critical success factors.

Table 1. Assessing normality (Kolmogorov-Smirnov test)

\begin{tabular}{llll}
\hline Success Factors & Kolmogorov-Smirnov & & Sig. \\
\hline Age & Statistic & df & 0.000 \\
Education & 0.312 & 118 & 0.000 \\
Entrepreneurial Orientation & 0.423 & 118 & 0.000 \\
Gender & 0.518 & 118 & 0.000 \\
Personality & 0.326 & 118 & 0.000 \\
Prior Experience & 0.385 & 118 & 0.000 \\
Enterprise Age & 0.401 & 0.000 \\
Business Networks & 0.331 & 0.000 \\
Customer Relations Management & 0.363 & 0.000 \\
Financial Resources & 0.514 & 118 & 0.000 \\
Internationalisation & 0.342 & 118 & 0.000 \\
Human Capital & 0.284 & 118 & 0.000 \\
Market Product Orientation & 0.385 & 118 & 0.000 \\
Marketing & 0.465 & 118 & 0.000 \\
Enterprise Size & 0.272 & 118 & 0.000 \\
Strategic Planning & 0.387 & 118 & 0.000 \\
Political Environment & 0.350 & 118 & 0.000 \\
Economic Environment & 0.278 & 118 & 0.000 \\
Socio-cultural Environment & 0.298 & 118 & 0.000 \\
Technological Environment & 0.434 & 118 & 0.000 \\
Legal / Regulatory Environment & 0.409 & 118 \\
Ecological Environment & 0.524 & 118 \\
\hline
\end{tabular}

\subsection{Validity and Reliability}

Test-Retest reliability was used to assess the reliability of the survey instrument. The exact questionnaire on critical success factors for small businesses was given to the same respondents on two separate occasions under the same conditions; T1 represented the first time the test was given and T2 the second time. On the first occasion (T1), 118 owners /managers responded positively to the survey. Three (3) months after the initial data collection (T2), the same questionnaire was resent to all respondents and within a period of three months, 81 responses were received back. All questionnaires were coded allowing T1 and T2 responses to be matched for the same respondents. Statistical comparisons were carried out on the participants' answers for the two different times. The Spearman's rho correlation test was utilised to test the null hypothesis that two populations are the same against an alternative hypothesis. The correlation between the two responses was tested through the test-retest reliability coefficient $\left(\mathrm{r}_{\mathrm{s}}\right)$, also known as the coefficient of stability. The coefficient can vary between 0 and 1 , with less than 0.5 indicating that the reliability of the instrument is not acceptable and 1 indicating excellent reliability, meaning that each respondent's scores were perfectly correlated.

Following statistical analysis (Spearman's rho correlation test) on 81 questionnaires the test-retest reliability coefficient $\left(r_{s}\right)$ for each of the success factors was found to vary between 0.909-0.989 (see Table 2) indicating a significant positive correlation at the 0.01 level for a two-tailed prediction. This meant that the participants' responses on the first (T1) and second (T2) occasions were significantly correlated and therefore the reliability of the instrument was excellent. 
Table 2. Spearman rho test-correlation coefficients $\left(r_{s}\right)$ for success factors

\begin{tabular}{ll}
\hline Success factors & Correlation Coefficient \\
\hline Age & 0.919 \\
Education & 0.909 \\
Entrepreneurial Orientation & 0.976 \\
Gender & 0.916 \\
Personality & 0.928 \\
Prior Work Experience and Management Skills & 0.946 \\
Enterprise Age & 0.935 \\
Business Networks & 0.963 \\
Customer Relations Management & 0.954 \\
Financial Resources & 0.951 \\
Internationalisation & 0.972 \\
Human Capital & 0.968 \\
Market Product Orientation & 0.974 \\
Marketing & 0.945 \\
Enterprise Size & 0.949 \\
Strategic Planning & 0.956 \\
Political Environment & 0.946 \\
Economic Environment & 0.979 \\
Socio-cultural Environment & 0.963 \\
Technological Environment & 0.932 \\
Legal / Regulatory Environment & 0.987 \\
Ecological Environment & 0.989 \\
\hline
\end{tabular}

Pilot testing was also utilised on a random sample $(n=20)$ of the target population to discover possible weaknesses, inadequacies, ambiguities and problems in all aspects of the research so corrections could be made before the actual data collection took place. All comments were positive, with some minor recommendations proposed on the format. Instructions were very clear and easy to follow. The questionnaire was found to be well written, easy to complete, with good coverage of the subject and with the time it took to complete being well received. Therefore, there was a high degree of confidence that the questionnaire was adequate to collect all the required data to achieve the aim of this research. The pre-test facilitated improving the content and enhancing construct validity.

\subsection{Critical Success Factors for SMEs in the UK Chemical Distribution Industry}

In order to identify the critical success factors for SMEs in the UK chemical distribution industry, non-parametric statistics were used to rank the data on factors influencing SMEs success. Success factors, as perceived by the respondents, were ranked using the Kruskal-Wallis test of variance. Following statistical analysis, there was a significant difference in the continuous variable across the 22 success factors under investigation, as the significance level (Sig.) was found to be less than 0.001 , df was 21 and Chi-Square 1847 (see Table 4). As a result, the Kruskal-Wallis mean rank value was used for ranking the success factors by importance. In support, the median and mode values were also reported. The higher the mean rank, the median and mode values of a factor, the more important this was for small business success in the UK chemical distribution industry and therefore was considered a critical success factor. Table 3 presents the Kruskall-Wallis mean rank, median and mode for each of the investigated success factors for small businesses in the UK chemical distribution industry, in descending order of importance. 
Table 3. Critical success factors analysis (Kruskal Wallis Test, Median and Mode)

\begin{tabular}{lllll}
\hline No. & Critical Success Factor & $\begin{array}{l}\text { Mean Rank } \\
\text { (Kruskal-Wallis) }\end{array}$ & Median & Mode \\
\hline 1 & Legal and Regulatory & 2049.69 & 5.00 & 5.00 \\
2 & Ecological and Environmental & 2044.16 & 5.00 & 5.00 \\
3 & Entrepreneurial Orientation & 2035.51 & 5.00 & 5.00 \\
4 & Customer Relations Management & 2028.42 & 5.00 & 5.00 \\
5 & Market and Product Development & 1937.76 & 5.00 & 5.00 \\
6 & Prior Work Experience and Management Skills & 1811.82 & 5.00 & 5.00 \\
7 & Human Capital & 1800.58 & 5.00 & 5.00 \\
8 & Economic Environment & 1650.76 & 4.00 & 4.00 \\
9 & Strategic Planning & 1642.97 & 4.00 & 4.00 \\
10 & Business Networks & 1555.43 & 4.00 & 4.00 \\
11 & Financial Resources & 1492.30 & 4.00 & 4.00 \\
12 & Personality & 1473.43 & 4.00 & 4.00 \\
13 & Education & 1127.47 & 4.00 & 4.00 \\
14 & Marketing & 1117.29 & 4.00 & 4.00 \\
15 & Internationalisation & 1063.14 & 3.50 & 3.00 \\
16 & Political Environment & 964.14 & 3.00 & 3.00 \\
17 & Technological Environment & 743.97 & 3.00 & 3.00 \\
18 & Socio-cultural Environment & 639.43 & 3.00 & 3.00 \\
19 & Size of firm & 397.19 & 2.00 & 2.00 \\
20 & Age of firm & 385.15 & 2.00 & 2.00 \\
21 & Age of owner / manager & 366.61 & 2.00 & 2.00 \\
22 & Gender & 238.77 & 2.00 & 2.00 \\
\hline & & & &
\end{tabular}

Frequency analysis (see Tables 5,6 and 7) further identified Entrepreneurial Orientation and Prior Work Experience and Management skills as the most important entrepreneurial, Customer Relations Management, Market and Product development, Human Capital and Strategic Planning as the most important enterprise and Regulatory Compliance and the Economic environment as the most important business environment success factors.

Table 4. Kruskal-Wallis test statistics

\begin{tabular}{ll}
\hline & Success Factors \\
\hline Chi-Square & 1847.252 \\
df & 21 \\
Asymp. Sig. & 0.000 \\
\hline
\end{tabular}

Table 5. Frequency analysis entrepreneurial factors

\begin{tabular}{lll}
\hline Entrepreneurial Factors & Frequency & Percent $\%$ \\
\hline Entrepreneurial Orientation & 66 & 55.9 \\
Prior Work Experience and Management Skills & 43 & 36.4 \\
Personality & 9 & 7.6 \\
\hline
\end{tabular}

Table 6. Frequency analysis enterprise factors

\begin{tabular}{lll}
\hline Enterprise Factors & Frequency & Percent $\%$ \\
\hline Customer Relations Management & 45 & 38.1 \\
Market and Product Development & 33 & 28.0 \\
Human Capital & 16 & 13.6 \\
Strategic Planning & 14 & 11.9 \\
Business Networks & 5 & 4.2 \\
Financial Resources & 3 & 2.5 \\
Internationalisation & 2 & 1.7 \\
\hline
\end{tabular}


Table 7. Frequency analysis business environment factors

\begin{tabular}{lll}
\hline Business Environment Factors & Frequency & Percent \\
\hline Legal-Regulatory Environment & 71 & 60.2 \\
Economic Environment & 45 & 38.9 \\
Technological Environment & 1 & .8 \\
\hline
\end{tabular}

Based on the Kruskall-Wallis mean rank, median and mode values and frequency analysis, hypotheses 1c (Entrepreneurial Orientation), if (Prior Work Experience and Management skills), 2c (Customer Relations Management), 2f (Human Capital), 2g (Market and Product Development, 2j (Strategic Planning), 3b (Economic), 3e (Legal and Regulatory) and $3 \mathrm{f}$ (Ecological and Environmental) were accepted; meaning that these factors were critical in the success of SMEs in the UK chemical distribution industry.

All the remaining hypotheses 1a (Age), 1b (Education level), 1d (Gender), 1e (Personality), 2a (Age of the company), 2b (Business Networks), 2d (Financial Resources), 2e (Internationalisation), 2h (Marketing), 2i (Size of company), 3a (Political), 3c (Socio-cultural) and 3d (Technological) were not accepted; meaning that these were considered non-critical for SMEs success in the specific industry.

The most important factors affecting the success of SMEs in the UK chemical distribution market are Legal and Regulatory and Ecological and Environmental. Complying with current legal requirements, coping with strong regulatory trends and overcoming future regulatory challenges are seen as critical in the success of small businesses in this industry.

However, it has long been established in the business literature that the use, production, transportation and safe disposal of chemicals has an adverse impact on both human health and the environment (European Chemical Agency, 2014; Keynote, 2013; Jerrentrup, 2009). As a result, the chemical and subsequently the chemical distribution industry having been traditionally heavily regulated with this trend having intensified in the recent years where a number of initiatives aim at developing industry-wide support for best-practice standards i.e. REACH, Biocide directive etc. (CEFIC, 2013; European Chemical Agency, 2014; Hiller, 2013). Therefore, it has never been uncommon practise for Ecological and Environmental requirements to develop into Legal and Regulatory requirements in this industry. In other words, ecological and environmental factors create and drive the need for regulation, which is subsequently expressed through legal and regulatory factors.

Statistical analysis was further used to investigate this relationship. As the collected data were ordinal in nature, the analysis was based on the Spearman's rank correlation coefficient (Spearman's rho). The co-efficient of correlation shows the strength of the relationship and can range from -1.00 to +1.00 (Pallant, 2007). If the relationship is perfect and one measure follows exactly from another, then the correlation value is 1.00 . On the other hand if there is no relationship, then the correlation value is 0.00 . If two measures are the exact opposites of each other, then the relationship is negative with a value of -1.00 (Rovai, Baker, \& Ponton, 2013). Also, the correlation co-efficient is statistically significant when it is sufficiently different from zero to exclude the possibility that the correlation between the two measures is achieved by chance; this is determined through the significance level (Sig. 2 tailed) (Knapp, 2014; Howell, 2013). The significance level is termed as the remaining risk that the similarity could have occurred by accident. For instance, if the significance level was 0.01 there would be a one in a hundred risk of this happening.

Following analysis (see Table 8), the majority of the correlations were found to be low or moderate suggesting the absence of multi-collinearity between the success factors. However, there was a large correlation between the Legal and Regulatory and Ecological and Environmental factors $(\mathrm{R}=0.999$, Sig $=0.000)$ suggesting that the respondents considered the importance of these two factors strongly correlated. This further reinforces the fact that these two factors are very closely related and interlinked with each other in the context of the UK chemical distribution industry. On the basis of the fact that owners/managers of this study consider these two factors as one prerequisite for success and consequently, this study reports and further analyses them both under the 'Regulatory compliance' umbrella. 
Table 8. Spearman rho correlation matrix analysis

\begin{tabular}{|c|c|c|c|c|c|c|c|c|c|}
\hline & & PriorExp & CRM & $\mathrm{HC}$ & MPD & Str.Plan & Econom & Legal-Reg & Eco-Enviro \\
\hline \multirow[t]{2}{*}{ EO } & $\mathrm{r}$ & 0.01 & -0.092 & 0.026 & -0.055 & 0.067 & -0.059 & 0.161 & 0.158 \\
\hline & Sig. & 0.918 & 0.322 & 0.777 & 0.554 & 0.468 & 0.528 & 0.082 & 0.087 \\
\hline \multirow[t]{2}{*}{ PriorExp } & $\mathrm{r}$ & 1 & 0.085 & -0.116 & 0.085 & -0.092 & 0.048 & $.353^{* *}$ & $.356^{* *}$ \\
\hline & Sig. & & 0.359 & 0.21 & 0.36 & 0.321 & 0.607 & 0 & 0 \\
\hline \multirow[t]{2}{*}{ CRM } & $\mathrm{r}$ & & 1 & $.234^{*}$ & 0.155 & -0.056 & $-.344^{* *}$ & $.297 * *$ & $.302 * *$ \\
\hline & Sig. & & & 0.011 & 0.094 & 0.545 & 0 & 0.001 & 0.001 \\
\hline \multirow[t]{2}{*}{$\mathrm{HC}$} & $\mathrm{r}$ & & & 1 & 0.155 & -0.057 & $-.190^{*}$ & 0.09 & 0.087 \\
\hline & Sig. & & & & 0.093 & 0.539 & 0.04 & 0.331 & 0.349 \\
\hline \multirow[t]{2}{*}{ MPD } & $\mathrm{r}$ & & & & 1 & $.207^{*}$ & -0.065 & 0.092 & 0.09 \\
\hline & Sig. & & & & & 0.025 & 0.482 & 0.321 & 0.335 \\
\hline \multirow[t]{2}{*}{ Str.Plan } & $\mathrm{r}$ & & & & & 1 & 0.081 & -0.071 & -0.074 \\
\hline & Sig. & & & & & & 0.383 & 0.443 & 0.424 \\
\hline \multirow[t]{2}{*}{ Econom } & $\mathrm{r}$ & & & & & & 1 & -0.149 & -0.151 \\
\hline & Sig. & & & & & & & 0.107 & 0.103 \\
\hline \multirow[t]{2}{*}{ Legal-Reg } & $\mathrm{r}$ & & & & & & & 1 & $.999 * *$ \\
\hline & Sig. & & & & & & & & 0 \\
\hline
\end{tabular}

EO: Entrepreneurial Orientation; PriorExp: Prior work experience and management skills; CRM: Customer relations management; HC: Human capital; MPD: Market and product development; Str.Plan: Strategic planning; Econom: Economic environment; Legal-Reg: Legal and regulatory environment; Eco-Enviro: Ecological and Environmental.

\section{Discussion and Concluding Remarks}

Overall and in line with small business literature (e.g. Dobbs \& Hamilton, 2007; Islam, Khan, Obaidullah, \& Alam, 2011; Simpson, Tuck, \& Bellamy, 2004), SMEs success in the UK chemical distribution industry is found to be dependent upon many factors being optimal simultaneously. In fact, it is a combination of factors and not a selected few that lead to business success; satisfying one or two factors does not necessarily guarantee success. In other words, this research recognises and establishes SMEs success as a multidimensional phenomenon, affected by both firm-internal (enterprise) and firm-external (entrepreneurial and business environment) factors. The general view of this study is that if small businesses strive towards satisfying the identified critical success factors (CSFs) then they will be successful and achieve sustainable growth. During this process and based on the fact that change is identified as the one constant feature to be faced by chemical distributors in the future, flexibility and adaptability are deemed very important assets for SMEs in the selected industry. The ability to keep changing and adapting to new market conditions quickly is also considered a key to success and sustainable growth.

This study establishes a positive relationship between eight (8) success factors and SMEs success in the UK chemical distribution industry: Regulatory Compliance, Entrepreneurial Orientation, Customer Relations Management, Market and Product development, Prior Work Experience and Management Skills, Human Capital, Economic Environment and Strategic Planning. Therefore, these factors are considered critical for small business success in the specific industry. This is the main theoretical contribution of this study, presented in Figure 2, also depicting the relative strength of each of the factors (based on the Kruskall Wallis Mean Rank, MR). 


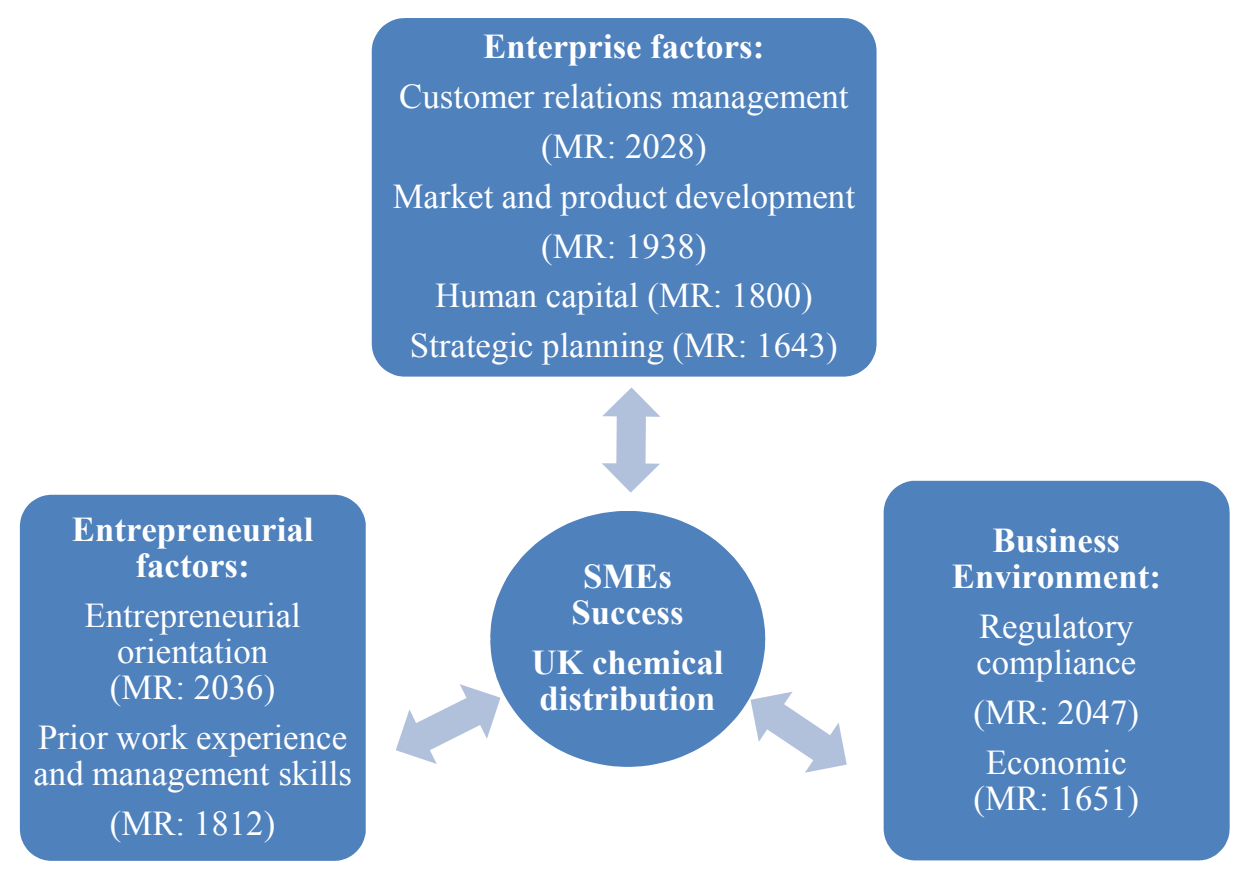

Figure 2. CSFs for SMEs in the UK chemical distribution industry

Despite the fact that SMEs, unlike their larger counterparts, are considered to be more flexible, adaptable and thus less being able to cope with the business environment more effectively (Adams, Khoja, \& Kauffman, 2011; Forsman, 2008; Raju, Lonial, \& Crum, 2012), this study concludes that regulatory compliance is unavoidable. Inevitably, all SMEs operating in the UK and European chemical distribution industry have to fully implement the measures necessary to comply with regulations otherwise face the real risk of being excluded from the market. A compliance strategy needs to be developed and implemented while a long-term, flexible outlook on regulatory requirements, especially on REACH and competition law, has to be maintained. Keeping a low profile or adopting a 'just say yes' approach would be meaningless.

The findings of this research further identify entrepreneurial orientation as a significant antecedent of business growth, a factor that has an overall positive effect on business performance and a source of differentiation or competitive advantage for SMEs in the UK chemical distribution industry. In fact, this study reinforces the strong relationship between EO and the longevity and long term performance of the business (Andersson \& Tell, 2009; Raunch, Wiklund, Lumpkin, \& Frese, 2009). Conversely, a lack of entrepreneurial orientation and attributes are further established as common reasons for small business failure and low entrepreneurial activity. In other words, should SMEs in the specific industry lack entrepreneurial behaviour - in means of risk-taking, innovativeness and pro-activeness - they are faced with stagnation and eventually failure, affecting the whole industry.

Taking into consideration the fact that chemical distribution is a service based industry - as distributors do not manufacture any products but only trade them - SMEs success and sustainable growth depend greatly upon providing excellent service and customer care. This distinct lack of manufacturing capabilities makes the service element a unique value-adding factor for this industry and as such it becomes imperative for SMEs to adopt and embrace customer relations management practices. Identifying and satisfying customer needs, is the cornerstone of business success and essential element to sustainable growth. Providing excellent service, maintaining good relationships and continuously delivering superior value to customers, providing tailor-made solutions and delivering innovation are the some of the most important aspects.

Based on the distinct absence of manufacturing capabilities, building up a well balanced portfolio of products and promoting that in the right markets, known as market and product development (MPD), is also crucial in the success of small UK chemical distributors. This research concludes that small businesses not only have to continuously enlarge, diversify and specialise their product portfolio but also expand their market reach in order to be successful and achieve sustainable growth. Distributors with deep knowledge of local market demands and trends are expected to excel at category management and thus be highly competitive in the market. Good product knowledge enables them to select the 'anchor' products of leading suppliers in particular applications. Similarly, 
with manufacturing capabilities continuously developing and diversifying, the risk from substitute products also needs to be taken into consideration and managed properly.

The study also establishes that an owner/manager's prior work and industry experience, management know-how, training and qualifications are beneficial and contributory to SMEs success. All these contributing factors in conjunction with prior knowledge of the products and their applications, raw materials, suppliers, regulatory requirements but most importantly customers and their needs, provide a solid basis upon which one builds a successful and sustainable business in the specific industry.

Human capital is found to be one of the most important resources for SMEs operating in the UK chemical distribution industry. This study ascertains that this is a very customer-focused and customer-facing industry with the human factor having a significant influence on business and further argues that the services offered by chemical distributors depend more on human rather than on technical or logistical resources. The already established fact that chemical distributors do not manufacture products further reinforces the importance of the element of service.

The economic environment also has a significant impact on small businesses in the UK chemical distribution industry, affecting short and long term planning and thus it needs to be taken under careful consideration. Even though it can be argued that the economy is beyond the control of any business, SMEs still need to cope and adapt to economic conditions, be flexible in their planning and maintain a proactive outlook allowing for change. Owners/managers and prospective entrepreneurs are urged to consider the economic environment carefully before investing or committing to business ventures in this industry. This study identifies a clear need to engage in financial planning, control and forecasting and incorporate economic conditions and variables into the business strategy. Concurrently, it also reveals a distinct lack of the financial skills and know-how necessary to perform these tasks on behalf of the owners/managers. This gap in skills and knowledge needs to be addressed either through the provision of training or the use of external advice. In other words, chemical distribution SMEs have to invest in internal training courses or external consultancy and further utilise any available support from the government and any industry associations.

Strategic planning for small UK chemical distributors needs to be concerned with the setting of long-term organisational goals, the development and implementation of plans to achieve these goals and the allocation or diversion of resources necessary for realising these goals. Given the fast moving nature of the chemical distribution industry (Districonsult, 2013; FECC, 2013), the constantly changing trends in the market and regulatory compliance requirements (Chemagility, 2015; Jung et al., 2014) the need to plan ahead and get strategically positioned is of paramount importance. In fact, the findings suggest that only strong and focused companies with a forward-looking strategy and mind-set will thrive in the UK chemical distribution industry and equally recognises that only those SMEs engaging in strategic planning are likely to achieve higher sales growth, margins on profit and employee growth. Furthermore, strategic planning is beneficial at all stages of the business, but most importantly in the start-up stage not only necessarily to guarantee success but to reduce the possibility of business failure.

There are also a number of factors that have not been identified as critical to the success of SMEs in the UK chemical distribution industry. This study concludes that business networking, financial resources, the personality and education of the owner/manager alongside marketing and internationalisation, even though still important, have a smaller impact on the success and sustainable growth of small chemical distributors operating in the UK and are thus referred to as non-critical. The political, technological and socio-cultural environment alongside the age and size of firm and age and gender of the owner/manager are considered of particularly low importance.

This study reveals a strong interdependency amongst the success factors and notes that a number of the aforementioned non-critical factors are incorporated, to a certain extent, into the identified CSFs. For instance, business networks are identified as an important part of the owners/managers' prior experience. Business contacts, anything from previous formal arrangements (i.e. joint ventures, alliances and distribution agreements) to informal networking (i.e. business clusters, business incubators, entrepreneurship clubs), are established as beneficial to small businesses by providing access to business ideas, resources, knowledge and capital while reducing risks. Similarly, the age of the owner/manager, in light of the experience, education, skills, financial and social capital accumulated over a long working career, is also mentioned under the prior working experience and skills success factor.

Furthermore, there is a significant overlap between the economic environment and financial resources with access to finance having been identified as the most significant element for both of these factors. The personality 
of the owner/manager and in particular those characteristics required for success and sustainable development, are discussed under entrepreneurial orientation. EO also incorporates elements of the political and socio-cultural environment as it establishes a lack of entrepreneurial education and the need to promote entrepreneurship and small business ownership, advisory services and SME-friendly policies. The educational level of owners/managers and its impact on small businesses form part of prior experience and skills and are also addressed under human capital.

Regarding marketing and as this is the management process responsible for identifying, anticipating and satisfying customer requirements profitably (CIM, 2015), many of its aspects are incorporated, discussed and analysed in regulatory compliance, customer relations management, market and product development and strategic planning. Internationalisation, as a way to develop and expand into new markets, is also identified as an integral part of the market and product development. Last, the technological environment is partly incorporated into CRM as technology is found to provide a significant support role to SMEs such as ICT skills, e-CRM systems for customers and suppliers, websites, databases while the advances in global logistics allow small businesses with fewer resources to compete and source products on a global basis.

\section{Contribution and Implications}

This research addresses a well-established gap in small business success in the UK chemical distribution industry as it is the first study to provide an integrative perspective of critical success factors (CSFs) for SMEs in this sector and there lies its original and significant contribution. By identifying the factors critical to the success and sustainable growth of UK chemical distribution SMEs, this study fulfils the need for more empirical studies in the specific research area and contributes to the unification of the different success factors frameworks.

SMEs owners/managers can utilise the findings of this study to strategize, run their businesses more efficiently and effectively - by concentrating their efforts and resources to the areas that really make a difference in their business -, plan and prepare for the future - including CSFs in their planning process and addressing any issues in the very early stage -, improve their decision-making process by basing their decisions on facts and experts' views, uncover and address training needs such as strategic and financial planning skills, lack of technical and regulatory expertise, product knowledge etc. This research further provides a set of tools for the prospective entrepreneur not only to assess the probability of success or failure before starting a business but also how to make it successful in the long term.

The Government, policy makers and financial institutions may utilise the findings of this study to develop and implement policies directed at SMEs in the specific industry; highlight areas of improvement; improve the effectiveness of interventions flowing from support policies; improve and develop the necessary support infrastructure; extend the nature and the range of advice and offer training and education for SME owners, managers and employees. This paper also provides a means to identify small businesses with potential high growth capabilities and provide more directional support.

Non-Government, industry specific organisations such as the European Federation of chemical distributors (FECC), the Chemical Business Association (CBA) and the British Association of Chemical Specialties (BACS), also benefit from this research as it increases their understanding of the industry, especially from a small business perspective, and offers valuable advice on SMEs success. It also provides the knowledge for these associations to approach and recruit new members, especially SMEs that have always been difficult to approach or the ones that did not see a value in joining before.

Last, chemical manufacturers and suppliers are able to get a deeper, more complete understanding of the market and SMEs operating in it. Therefore, they would be in a position to evaluate, formulate and implement their distribution channel strategy in a more efficient and effective way.

Regarding limitations, as this is a UK study, the findings may lack generalisability and therefore further research is required to test the identified success factors in different geographical areas and industries. Also, due to the lack of financial data, the identification of the CSFs was based on the opinion of the owners/managers and not on an objective measure of success (turnover and profitability). Last, absence of official statistical data further meant that a combination of academic and industry sources was utilised to compile a list of the target population and as such allowances should be made for omissions due to human error and for the fact that the total number of SMEs operating in this industry may have changed since the time of the study.

Future research should concentrate on more cross-country and cross-industry data and utilise independent growth measures, i.e. increase in turnover and/or profitability, towards a more unified model of small business success. Conversely, there is further scope to identify and examine the factors that contribute to failure. In addition, due to 
the dynamic nature of the industry and the presence of strong globalisation and consolidation trends, longitudinal studies should be employed to investigate whether success factors change with time. Further qualitative research would provide a deeper understanding of the way specific factors impact on success.

\section{References}

Adams, J. H., Khoja, F. M., \& Kauffman, R. (2012). An Empirical Study of Buyer-Supplier Relationships within Small Business Organizations. Journal of Small Business Management, 50(1), 20-40. http://dx.doi.org/10.1111/j.1540-627X.2011.00342.x

Amorós, J. E., Bosma, N. S., \& Levie, J. (2013). Ten Years of Global Entrepreneurship Monitor: Accomplishments and Prospects. International Journal of Entrepreneurial Venturing, 5(2), 120-152. http://dx.doi.org/10.1504/IJEV.2013.053591

Andersson, S., \& Tell, J. (2009). The relationship between the manager and growth in small firms. Journal of Small Business and Enterprise Development, 16(4), 586-598. http://dx.doi.org/10.1108/14626000911000938

Arasti, R., Zandi, F., \& Talebi, R. (2012). Exploring the Effect of Individual Factors on Business Failure in Iranian New Established Small Businesses. International Business Research, 5(4), 2-11. http://dx.doi.org/10.5539/ibr.v5n4p2

Benzing, C., Chu, H. M., \& Kara, O. (2009). Entrepreneurs in Turkey: A Factor Analysis of Motivations, Success Factors, and Problems. Journal of Small Business Management, 47(1), 58-91. http://dx.doi.org/10.1111/j.1540-627X.2008.00262.x

Brannback, M., Kiviluoto, N., Carsrud, A., \& Ostermark, R. (2010). Much Ado about nearly nothing? An Exploratory Study on the Myth of High-growth Technology Start-up Entrepreneurship, Frontiers of Entrepreneurship Research. Retrieved from http://digitalknowledge.babson.edu/fer/vol30/iss12/1

Chawla, S. K., Khanna, D., \& Chen J. (2010). Are Small Business Critical Success Factors Same in Different Countries? SIES Journal of Management, 7(1), 1-12.

Chemagility. (2008). UK Chemical Distributor Market Report 2008: Information, Insight and analysis of the UK Chemical distribution industry. Surrey: Chemagility.

Chemagility. (2012). A Global Perspective on the World Chemical Distribution Market, First Panel Session: Chemical Distribution Industry Landscape, FECC Annual Congress, Lisbon, May 21-23, 2012. Retrieved May 29, 2015, from http://www.assicconline.it/menu/documents/06_brown.pdf.

Chemagility. (2015). United Kingdom Chemical Distribution Report 2015. Surrey: Chemagility.

Chemical Business Association [CBA]. (2015). CBA Supply Chain Trends March 2015. Retrieved May 11, 2015, from http://www.chemical.org.uk/news/cbanews/cbasupplychaintrendsmarch2015.aspx

Davidsson, P., Steffens, P., \& Fitzsimmons, J. (2009). Growing Profitable or Growing from Profits: Putting the Horse in Front of the Cart? Journal of Business Venturing, 24(4), 388-406. http://dx.doi.org/10.1016/j.jbusvent.2008.04.003

Districonsult. (2013). Old Game-New Rules? Chemical Distribution in the Age of Volatility. Retrieved February27, 2015 , http://www.districonsult.com/en/index-districonsult\%2Bnewsletter-1-34\%2B \%2Bold\%2Bgame\%2Bnew \%2Brules\%2B2013.html.

Dobbs, M., \& Hamilton, R. T. (2007). Small business growth: Recent evidence and new directions. International Journal of Entrepreneurial Behaviour and Research, 13(5), 296-322. http://dx.doi.org/10.1108/13552550710780885

European Association of Chemical Distributors [FECC]. (2011). Communication in the supply chain-distributors ' challenges, ECHA - ENES Meeting 24th-25th November 2011, Brussels. Retrieved June 25, 2015, from https://echa.europa.eu/documents/10162/13587/echa_enes_jensen_korte_en.pdf/

European Association of Chemical Distributors [FECC]. (2013). The Chemical distribution Sector in Europe. Retrieved June 6, 2015, from http://www.fecc.org/fecc/about-fecc/the-chemical-distribution-sector-in-europe.

European Association of Chemical Distributors [FECC]. (2015). European business plan 2015. Retrieved February 20, 2015, from http://www.fecc.org/fecc/images/stories/downloads/GTDP/2014/FECC_BusPlan_2015_def.pdf/ 
European Chemical Industry Council [CEFIC]. (2013). The European chemical Industry: Facts and Figures 2013. Retrieved June 15, 2015, from http://www.cefic.org/Facts-and-Figures

European Chemicals Agency [ECHA]. (2014). About us. Retrieved January 19, 2015, from http://echa.europa.eu

European Union. (2015). Fact and figures about the EU's Small and Medium Enterprise (SMEs). Retrieved May 15, 2015, from http://ec.europa.eu/enterprise/policies/sme/facts-figures-analysis/index_en.htm

Forsman, H. (2008). Business development success in SMEs: A case study approach. Journal of Small Business and Enterprise Development, 15(3), 606-622. http://dx.doi.org/10.1108/14626000810892382

Franco, M., \& Haase, H. (2010). Failure factors in small and medium-sized enterprises: Qualitative study from an attributional perspective. International Entrepreneurship and Management Journal, 6(4), 503-521. http://dx.doi.org/10.1007/s11365-009-0124-5

Gray, D., Saunders, M., \& Goregaokar, H. (2012). Success in challenging times: Key lessons for UK SMEs. Surrey: University of Surrey.

Halabi, C. E., \& Lussier, R. N. (2014). A model for predicting small firm performance. Journal of Small Business and Enterprise Development, 21(1), 4-25. http://dx.doi.org/10.1108/JSBED-10-2013-0141

Hillary, R. (2000). Small and Medium - Sized Enterprises and the Environment: Business Imperatives. Sheffield: Greenleaf Publishing Ltd.

Hillier, S. (2013). Making the chemical-using industries more sustainable. TCE: The Chemical Engineer, 860(1), 26-27.

Hornke, M. (2012). Chemical Distribution 2012. Retrieved February 20, 2015, from http://www.chemanager-online.com/file/track/11755/1 /

Hornke, M. (2013). The future of chemical distribution in Europe: Customer relations as key value lever. Journal of business Chemistry, 9(2), 65-66.

Howell, D. C. (2013). Statistical methods for psychology (8th ed.). London: Wadsworth Cengage Learning.

Islam, A., Khan, M. A., Obaidullah A. Z. M., \& Alam, M. S. (2011). Effect of Entrepreneur and Firm Characteristics on the Business Success of Small and Medium Enterprises (SMEs) in Bangladesh. International Journal of Business and Management, 6(3), 289-299.

Jerrentrup, R. (2009). The Effects of the Financial Crisis on the Future of the Chemical Industry. Journal of Business Chemistry, 6(1), 3-6.

Jung, U., Wolleswinkel, R., Hoffmann, C., \& Rothman, A. (2014). Specialty Chemical Distribution-Market Update, Boston Consulting Group. Retrieved April 17, 2015, from https://www.bcgperspectives.com/content/articles/process_industries_go_to_market_strategy_specialty_che mical_distribution_market_update/?chapter=2 .

Kader, R. A., Mohamad, M. R., \& Ibrahim, A. A. (2009). Success factors for small rural entrepreneurs under the one- district-one-industry programme in Malaysia. Contemporary Management Research, 5(2), 147-162. http://dx.doi.org/10.7903/cmr.1173

Keskin, H. (2006). Market orientation, learning orientation, and innovation capabilities in SMEs. European Journal of Innovation Management, 9(4), 396-417. http://dx.doi.org/10.1108/14601060610707849

Keynote. (2013). Business ratio Report: Chemical Distributors UK. Richmond upon Thames: Key Note.

Kiviluoto, N., Brannback, M., \& Carsrud, A. (2011). Are Firm Growth and Performance the Same or Different Concepts in Empirical Entrepreneurship Studies? An Analysis of the Dependent and Independent Variables. In M. Raposo, D. Smallbone, K. Balaton, \& L. Hortovanyi (Eds.), Entrepreneurship, Growth and Economic Development (pp. 11-29), Cheltenham: Edward Elgar. http://dx.doi.org/10.4337/9780857934901.00007

Knapp, H. (2014). Introductory statistics using SPSS. Thousand Oaks, CA: SAGE.

Krasniqi, B. A., Shiroka-Pula, J., \& Kutllovci, E. (2008). The determinants of entrepreneurship and small business growth in Kosova: evidence from new and established firms. International Journal of Entrepreneurship and Innovation Management, 8(3), 320-342. http://dx.doi.org/10.1504/IJEIM.2008.019533

Kronimuns, A., Roos, A., \& Stelter, D. (2009). M\&A: Ready for Lift-off? A survey of European companies' Merger and Acquisition Plans for 2010. Boston consulting Group. Retrieved from https://www.bcg.com/documents/file36677.pdf 
Lampadarios, E. (2015). Critical success factors for SMEs: An empirical study in the UK chemical distribution industry (Unpublished doctoral dissertation). Leeds Beckett University, Leeds, UK.

Lampadarios, E., Kyriakidou, N., \& Smith, G. J. (n. d.). Towards a new framework for SMEs success: a literature review. International Journal of Business and Globalisation.

Lee, M. K. O., \& Cheung, C. M. K. (2004). Internet Retailing Adoption by Small-to-Medium Sized Enterprises (SMEs): A Multiple-Case Study. Information Systems Frontiers, 6(4), 385-397. http://dx.doi.org/10.1023/B:ISFI.0000046379.58029.54

Lin, W. B. (2006). A comparative study on the trends of entrepreneurial behaviors of enterprises in different strategies: Application of the social cognition theory. Expert Systems with Applications, 31(2), 207-220. http://dx.doi.org/10.1016/j.eswa.2005.09.036

Lussier, R. N., \& Halabi C. E. (2010). Three-Country Comparison of the Business Success versus Failure Prediction Model. Journal of Small Business Management, 48(3), 360-377. http://dx.doi.org/10.1111/j.1540-627X.2010.00298.x

McLarty, R., Pichanic, M., \& Sarapova, J. (2012). Factors Influencing the Performance of Small to Medium-Sized Enterprises: An Empirical Study in the Czech Republic. International Journal of Management, 29(3), 36-47.

Mortelmans, S., \& Reniers, G. (2012). Chemical distribution in Belgium from 2007 to 2010: An empirical study. Journal of Business Chemistry, 9(2), 105-113.

O'Cass, A., \& Weerawardena, J. (2009). Examining the role of international entrepreneurship, innovation and international market performance in SME internationalisation. European Journal of Marketing, 43(11-12), 1325-1348. http://dx.doi.org/10.1108/03090560910989911

Ojala, A. (2009). Internationalization of knowledge-intensive SMEs: The role of network relationships in the entry to a psychically distant market. International Business Review, 18(1), 50-59. http://dx.doi.org/10.1016/j.ibusrev.2008.10.002

Pallant, J. (2007). SPSS Survival Manual (3rd ed.). Philadelphia: Open University Press.

Plimsoll. (2013). Plimsoll Analysis: UK Chemical Wholesalers \& Distributors Industry - Individual Company Analysis. Stockton on Tees: Plimsoll Publishing Limited.

Raju, P. S., Lonial, S. C., \& Crum, M. D. (2011). Market orientation in the context of SMEs: A conceptual $\begin{array}{llll}\text { framework. Journal of Business } & \text { Research, 64(12), }\end{array}$ http://dx.doi.org/10.1016/j.jbusres.2010.12.002

Rauch, A., Wiklund, J., Lumpkin, G., \& Frese, M. (2009). Entrepreneurial orientation and business performance: an assessment of past research and suggestions for the future. Entrepreneurship, Theory and Practice, 33(3), 761-787. http://dx.doi.org/10.1111/j.1540-6520.2009.00308.x

Revell, A., \& Rutherfoord, R. (2003). UK environmental policy and the small firm: Broadening the focus. Business Strategy and the Environment, 12(2), 26-35. http://dx.doi.org/10.1002/bse.347

Rogoff, E. G., Lee, M. S., \& Suh, D. C. (2004). “Who Done It?” Attributions by Entrepreneurs and Experts of the Factors that Cause and Impede Small Business Success. Journal of Small Business Management, 42(4), 364-376. http://dx.doi.org/10.1111/j.1540-627X.2004.00117.x

Ropega, J. (2011). The Reasons and Symptoms of Failure in SMEs. International Advanced Economic Research, 17(4), 476-483. http://dx.doi.org/10.1007/s11294-011-9316-1

Rovai, P. A., Baker, D. J., \& Ponton, K. M. (2013). Social science research design and statistics: A practitioner's guide to research methods and IBM SPSS analysis. Chesapeake: Watertree Press LLC.

Simpson, M., Padmore, J., \& Newman, N. (2012). Towards a new model of success and performance in SMEs. International Journal of Entrepreneurial Behaviour and Research, 18(3), 264-285. http://dx.doi.org/10.1108/13552551211227675

Simpson, M., Tuck, N., \& Bellamy, S. (2004). Small business success factors: The role of education and training. Education and Training, 46(8), 481-491. http://dx.doi.org/10.1108/00400910410569605

Smallbone, D., \& Wyer, P. (2000). Growth and development in the small firm. In S. Carter, \& D. James-Evans (Eds.), Enterprise and Small Business. Harlow: Prentice Hall.

Smallbone, D., Welter, F., Voytovich, A., \& Egorov, I. (2010). Government and entrepreneurship in transition economies: the case of small firms in business services in Ukraine. Service Industries Journal, 30(5), 655-670. 
http://dx.doi.org/10.1080/02642060802253876

Steffens, P., Davidsson, P., \& Fitzsimmons, J. (2009). Performance Configuration over Time: Implications for Growth- and Profit-oriented Strategies. Entrepreneurship: Theory and Practice, 33(1), 125-148. http://dx.doi.org/10.1111/j.1540-6520.2008.00283.x

Unger, J. M., Rauch, A., Frese, M., \& Rosenbusch, N. (2011). Human capital and entrepreneurial success: A meta-analytical review. Journal of Business Venturing, 26(3), 341-358. http://dx.doi.org/10.1016/j.jbusvent.2009.09.004

Watson, K., Hogarth-Scott, S., \& Wilson, N. (1998). Small business start-ups: success factors and support implications. International Journal of Entrepreneurial Behaviour and Research, 4(3), 217-238. http://dx.doi.org/10.1108/13552559810235510

Wilson, C. D. H., Williams, I. D., \& Kemp, S. (2012). An evaluation of the impact and effectiveness of environmental legislation in small and medium-sized enterprises: Experiences from the UK. Business Strategy and the Environment, 21(3), 141-156. http://dx.doi.org/10.1002/bse.720

\section{Copyrights}

Copyright for this article is retained by the author(s), with first publication rights granted to the journal.

This is an open-access article distributed under the terms and conditions of the Creative Commons Attribution license (http://creativecommons.org/licenses/by/3.0/). 